\title{
The Keasler site (41HS235), a Titus Phase Cemetery in the Little Cypress Creek Basin, Harrison County, Texas
}

Timothy K. Perttula

Heritage Research Center, Stephen F. Austin State University

Follow this and additional works at: https://scholarworks.sfasu.edu/ita

Part of the American Material Culture Commons, Archaeological Anthropology Commons, Environmental Studies Commons, Other American Studies Commons, Other Arts and Humanities Commons, Other History of Art, Architecture, and Archaeology Commons, and the United States History Commons

Tell us how this article helped you.

This Article is brought to you for free and open access by the Center for Regional Heritage Research at SFA ScholarWorks. It has been accepted for inclusion in Index of Texas Archaeology: Open Access Gray Literature from the Lone Star State by an authorized editor of SFA ScholarWorks. For more information, please contact cdsscholarworks@sfasu.edu. 


\section{The Keasler site (41HS235), a Titus Phase Cemetery in the Little Cypress Creek Basin, Harrison County, Texas}

\section{Creative Commons License}

\section{(c) (1) \&}

This work is licensed under a Creative Commons Attribution-NonCommercial 4.0 International License 


\title{
The Keasler site (41HS235), a Titus Phase Cemetery in the Little Cypress Creek Basin, Harrison County, Texas
}

\author{
Timothy K. Perttula
}

\section{INTRODUCTION AND SITE SETTING}

The Keasler site (41HS235) is a Late Caddo period, Titus phase (ca. A.D. 1430-1680) cemetery in the East Texas Pineywoods (Figure 1). The site was excavated by collectors in the late 1970s, including Red McFarland, one of the more active looters of Caddo burials in East Texas. Minimal records on the burials at the site, and their contents, were provided by McFarland to the Texas Archeological Research Laboratory at The University of Texas (TARL).

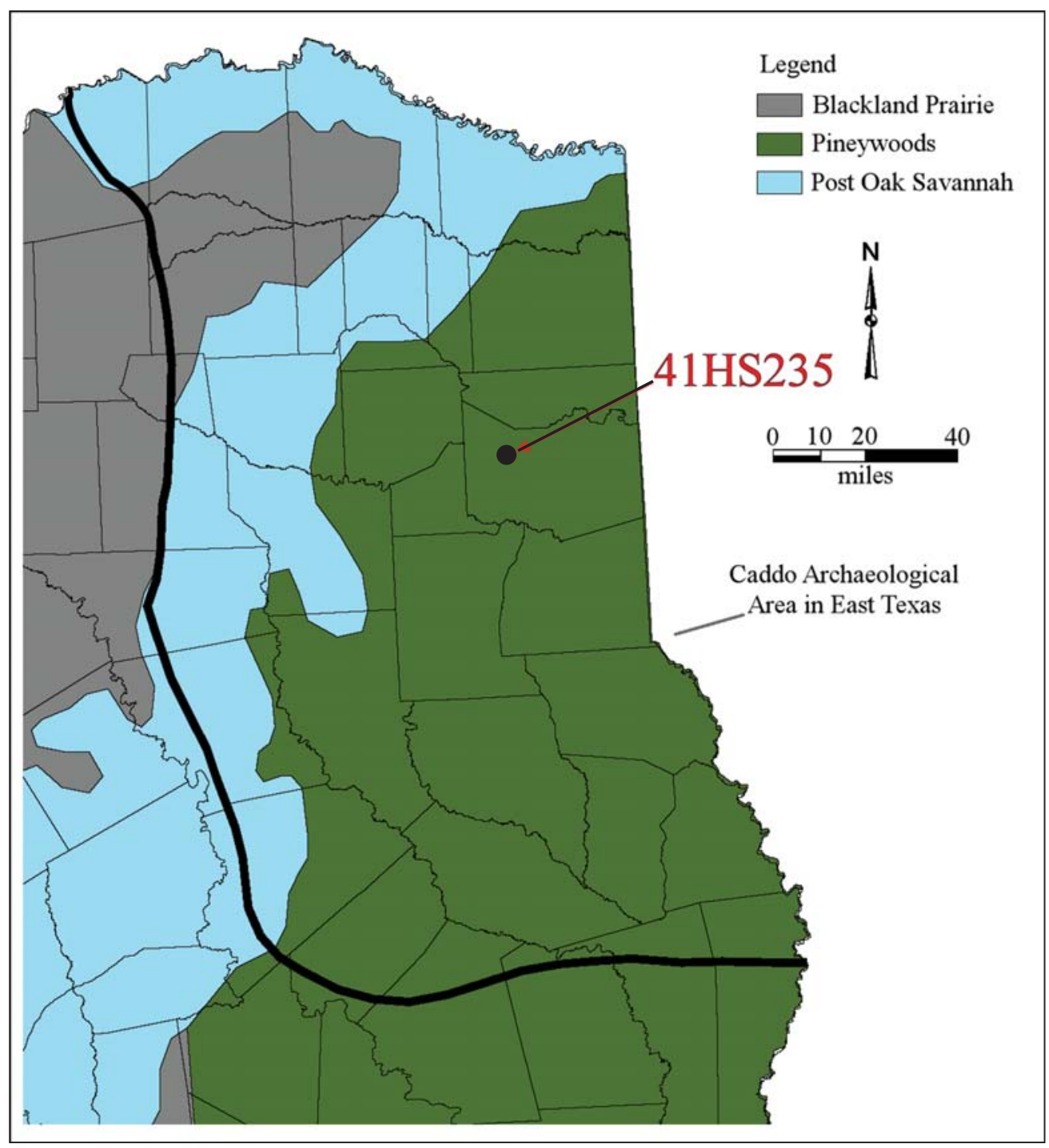

Figure 1. The location of the Keasler site (41HS235) in East Texas. 
The Keasler site is near Little Creek, a northward-flowing tributary to Little Cypress Creek. It is perhaps one of the easternmost-known Titus phase cemeteries in East Texas (see Perttula 2012:Figure 13-2 and Table 13-3), in an area where few Titus phase sites or cemeteries have been identified or investigated by professional archaeologists.

\section{CEMETERY INVESTIGATIONS}

During the course of the work at the cemetery by the various collectors, a total of 31 ancestral Caddo burials were excavated over an area roughly $18 \mathrm{~m}$ north-south and $12.2 \mathrm{~m}$ east-west (Figure 2). Twentyfive (81 percent) of the burials have east-west oriented pits where the deceased was laid out in the grave in an extended supine position, with their head facing to the west towards the House of Death in the Sky (Perttula 2012:393); this is the typical orientation of Titus phase burials. The other six burials (19 percent) were oriented generally in a northwest-southeast direction (Figure 2), with the head of the deceased facing towards the northwest (Table 1). The two different groups of burials do not spatially overlap (the only case where burials overlap is Burials 5 and 11 in the center of the cemetery, both among the east-west-oriented group of burials (Figure 2), and there is no archaeological information available in the limited notes about the cemetery or the different burials that would suggest the two groups of burials were not generally contemporaneous. This begs the question of the meaning of the two different burial orientations at the site, but does suggest that a diversity of beliefs about the afterlife were present in the Caddo community that used the Keasler site cemetery.

The east-west-oriented group of burials range from $152-188 \mathrm{~cm}$ in length and $61-112 \mathrm{~cm}$ in width, while the northwest-southeast-oriented group of burials are from $165-170 \mathrm{~cm}$ in length and $56-81 \mathrm{~cm}$ in width (see Table 1). Other than a few burial features in the east-west group of burials that are somewhat longer and wider, the burial pits among both burial groups are generally the same size, suggesting they held the remains of ancestral Caddo adults. The burial pits fall within the range of burial pit sizes in other Titus phase cemeteries (Burden et al. 2014:421). Burial pit depths are variable in both groups of burials, ranging from $46-122 \mathrm{~cm}$ in the east-west burial group and 66-112 cm in the northwest-southeast burial group (see Table 1). The deeper burial pits are not distinguished by numerically or quantitatively distinctive funerary offerings.

\section{Funerary Offerings}

With respect to the funerary offerings placed with the deceased in both groups, it is difficult to be very specific about any differences or similarities in their number and kind because the sketchy notes at TARL only quantify the number of ceramic vessels in each burial (see Table 1). In other cases, clay elbow pipes, arrow points, and celts are mentioned as funerary offerings, as is yellow and purple clay pigment, but the number of such offerings is not in the notes at TARL. A deer antler is mentioned as a funerary offering for Burial 7, having been placed inside a brushed bowl.

In the east-west oriented group of burials, there are 117 ceramic vessels, a mean of 4.7 vessels per burial (range from 0-11). A total of 16 percent of the burials in this group did not have ceramic vessel funerary offerings; the proportion of burials in the northwest-southeast oriented group of burials without ceramic vessel offerings is 17 percent. However, the mean number of ceramic vessels per burial in this group is 30 percent higher, at 6.2 (range from 0-12). The means of ceramic vessels in the burials in the two groups fall at the low end for Titus phase burials, where a recent analysis of cemeteries has shown that the mean frequency of vessels is $8.1 \pm 3.8$ per burial (Burden et al. 2014:423). Clay elbow pipes (Figure 3) are more common in the northwest-southeast group of burials (33 percent of the burials) than they are in the east-west group of burials (12 percent). Arrow points of unknown form are present in burial features in both burial groups. These subtle differences between burial groups in the number and kind of funerary offerings "do not show much evidence of differential status or social rank" (Perttula 2012:400), and the frequency of funerary 


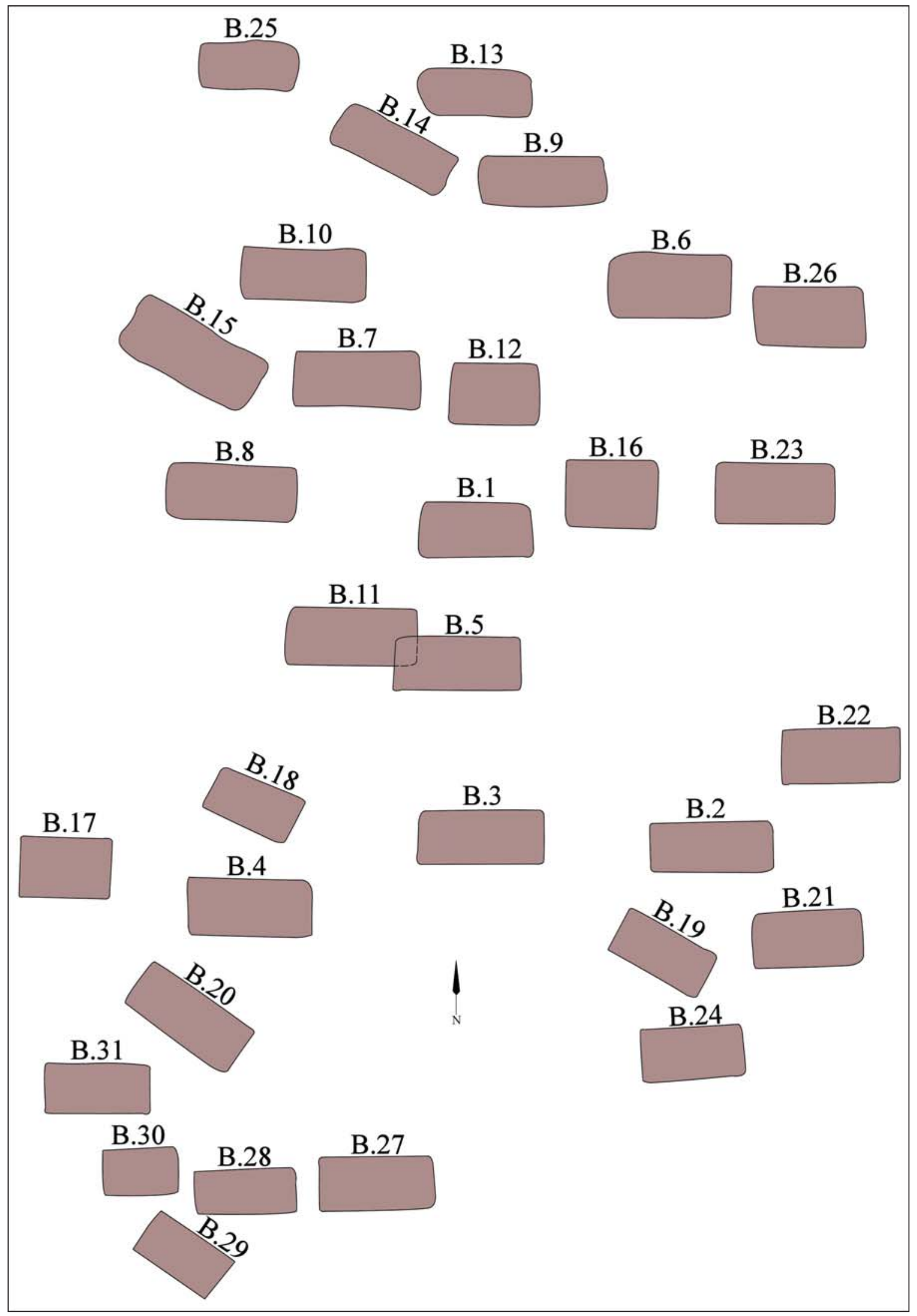

Figure 2. Plan map of Burials 1-31 at 41HS235. 
Table 1. Available information on the burial features at the Keasler site.

\begin{tabular}{|c|c|c|c|c|}
\hline $\begin{array}{l}\text { Burial } \\
\text { No. }\end{array}$ & $\begin{array}{l}\text { Length } x \text { Width } \\
(\mathrm{cm})\end{array}$ & $\begin{array}{l}\text { Depth } \\
(\mathrm{cm})\end{array}$ & $\begin{array}{l}\text { No. of } \\
\text { Vessels }\end{array}$ & Comments \\
\hline
\end{tabular}

\section{East-west oriented burial features}

\begin{tabular}{|c|c|c|c|c|}
\hline 1 & $175 \times 71$ & 91 & 4 & \\
\hline 2 & $158 \times 66$ & $89-94$ & 6 & \\
\hline 3 & $165 \times 61$ & 102 & 5 & \\
\hline 4 & N/A & 61 & 5 & \\
\hline 5 & N/A & 71 & 3 & \\
\hline 6 & N/A & N/A & 9 & \\
\hline 7 & $165 \times 71$ & 99 & 8 & $\begin{array}{l}\text { Clay pipe; deer antler } \\
\text { in brushed bowl }\end{array}$ \\
\hline 8 & $165 \times 71$ & 99 & - & Arrow points; clay pipe \\
\hline 9 & $152 \times 71$ & 76 & 6 & \\
\hline 10 & $168 \times 91$ & 107 & 2 & Arrow points; clay pipe \\
\hline 11 & $152 \times 71$ & 91 & 5 & \\
\hline 12 & N/A & 76 & 5 & \\
\hline 13 & N/A & 61 & 5 & \\
\hline 16 & $165 \times \mathrm{N} / \mathrm{A}$ & 76 & - & \\
\hline 17 & $165 \times 69$ & 107 & 6 & Taylor Engraved vessel \\
\hline 21 & $168 \times 76$ & 122 & 1 & \\
\hline 22 & $186 \times 76$ & 61 & 4 & \\
\hline 23 & $188 \times 112$ & 91 & - & \\
\hline 24 & N/A & N/A & 8 & Cass Appliqued vessel \\
\hline 25 & $186 \times 81$ & 97 & 8 & \\
\hline 26 & $\mathrm{~N} / \mathrm{A}$ & N/A & 4 & \\
\hline 27 & N/A & N/A & 8 & \\
\hline 28 & N/A & N/A & - & \\
\hline 30 & N/A & 46 & 5 & \\
\hline 31 & N/A & N/A & 11 & $\begin{array}{l}\text { Taylor Engraved vessel; large } \\
\text { utility ware vessel }\end{array}$ \\
\hline
\end{tabular}

\section{Northwest-southeast oriented burial features}

$\begin{array}{llrrl}14 & \text { N/A } & 66 & 6 & \\ 15 & 170 \times 81 & 81 & 12 & \text { Clay pipe; arrow point } \\ 18 & 170 \times 71 & 112 & - & \text { Clay pipe } \\ 19 & 165 \times 56 & 71 & 10 & \\ 20 & 168 \times 76 & 91 & 2 & \text { Taylor Engraved vessel } \\ 29 & \text { N/A } & \text { N/A } & 7 & \end{array}$

offerings is at the low end of the scale in Titus phase cemeteries (Perttula 2012:Table 13-4). The burials at the Keasler site appear to be common members of the community, and fall in what Burden et al. (2014:425) would call Group 1 and Group 2 burials; Group 1 burials have no indication of social status, while the few Group 2 burials (Burials 15 and 31) have higher numbers of ceramic vessels. In general, the burials at the Keasler site family cemetery "have little indication of variable burial treatment based on status" (Burden et al. 2014:431). 


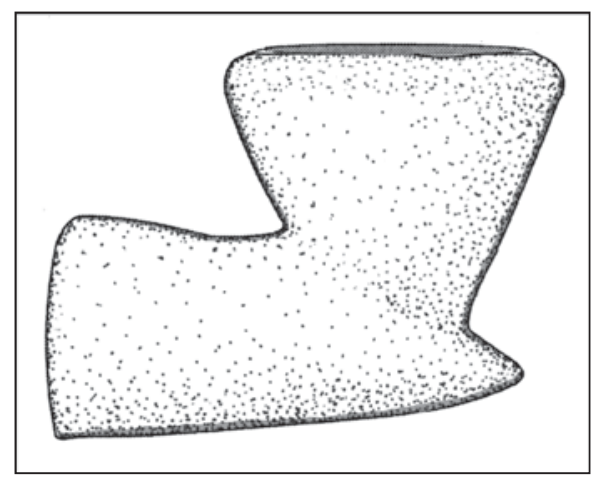

Figure 3. Clay elbow pipe from one of the burial features at the Keasler site.

Available notes and drawings regarding the ceramic vessels placed in the burials as funerary offerings indicate that among the utility wares are Belcher Ridged, Cass Appliqued (Figure 4), Harleton Appliqued, and Karnack Brushed-Incised (Figure 5) jars. The presence of at least one Belcher Ridged vessel suggests use of the cemetery after ca. A.D. 1500 (see Kelley 2012), and also suggests that there was interaction between Titus phase and Belcher phase Caddo groups on the Red River in the Great Bend area and below and in East Texas, respectively.

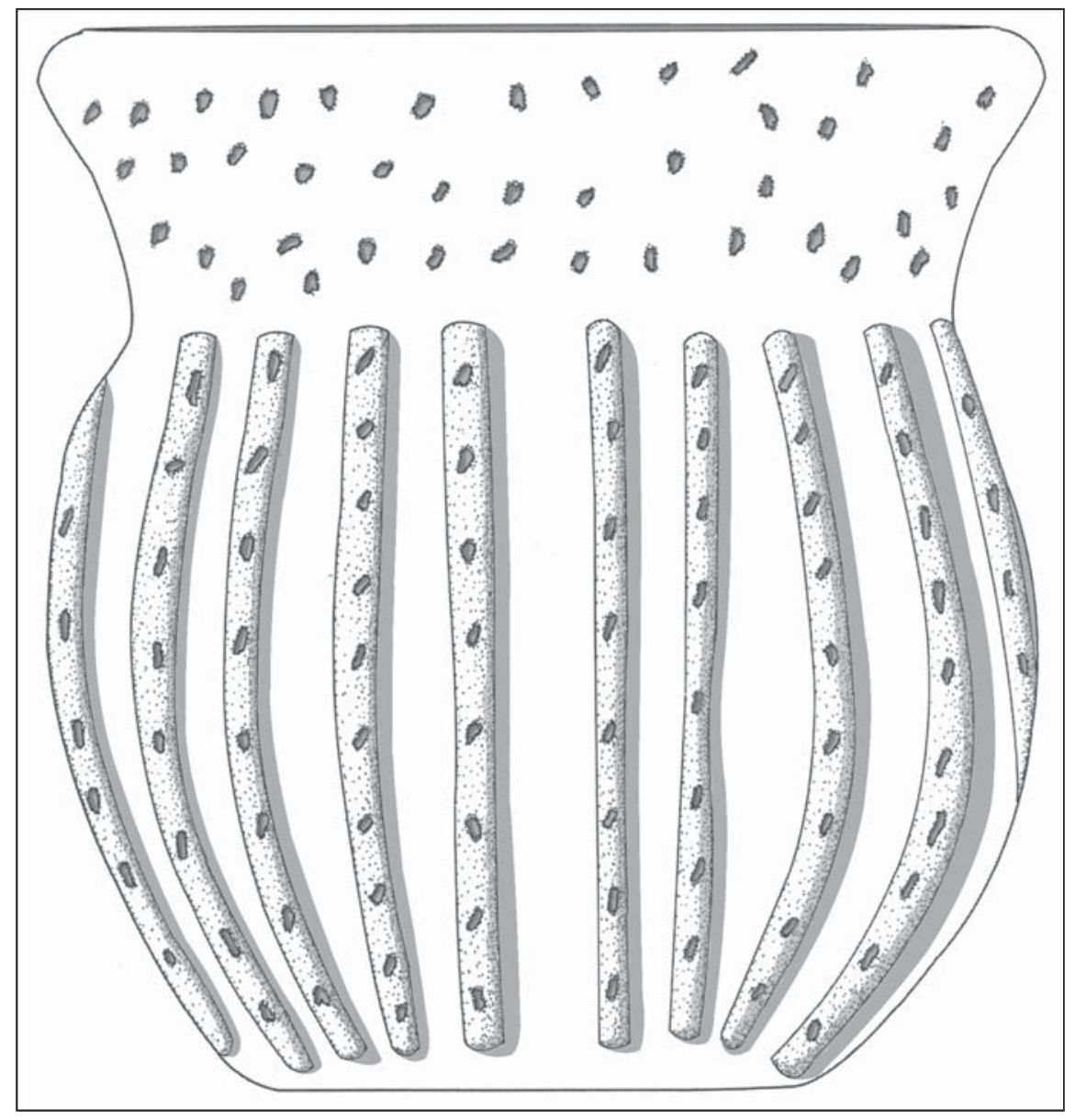

Figure 4. Cass Appliqued jar from one of the burial features at the Keasler site. 


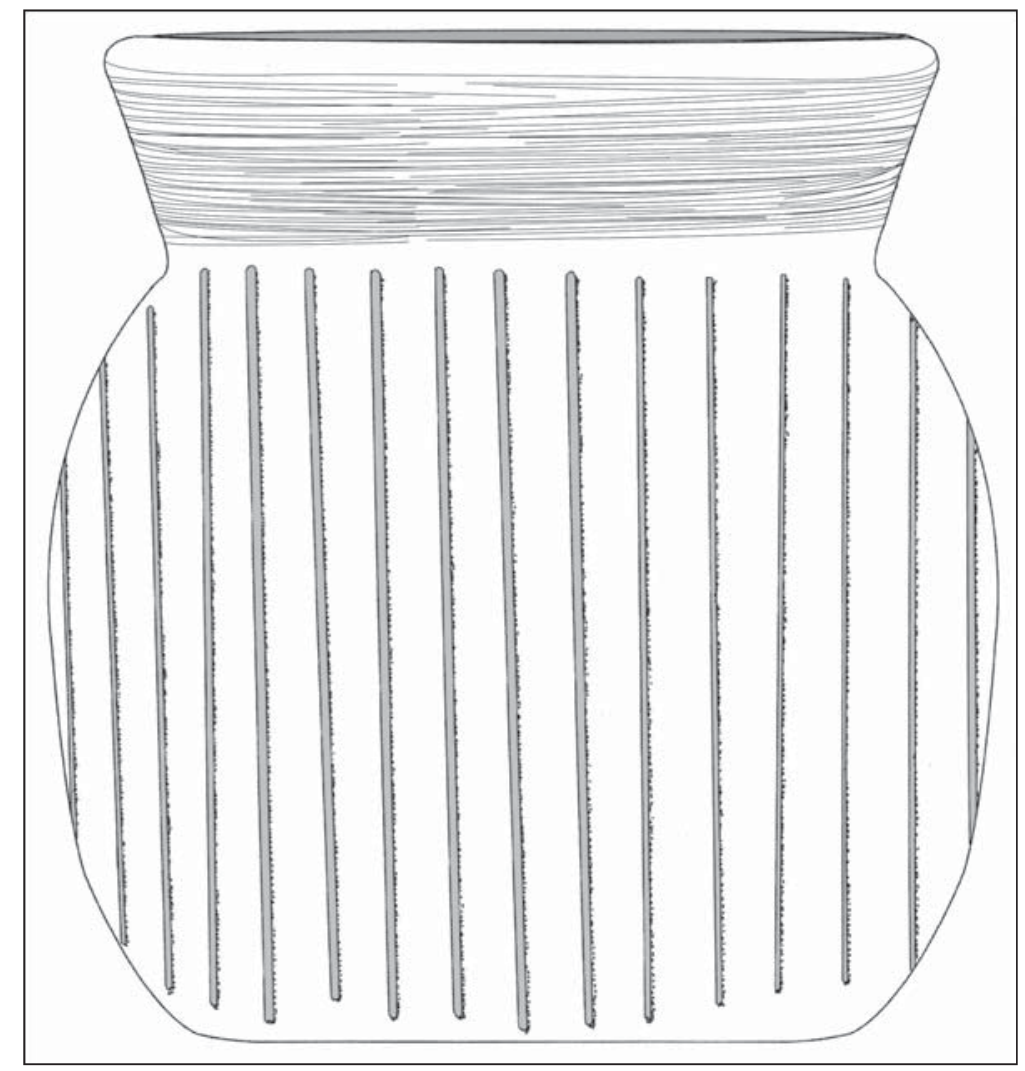

Figure 5. Karnack Brushed-Incised jar from one of the burial features at the Keasler site.

Fine ware vessels in burial features include several varieties of Ripley Engraved (var. Carpenter, var. Galt, var. McKinney, var. Richey, var. Williams, and var. unspecified) carinated bowls and compound bowls (Figures 6-9; see Perttula et al. 2012; Fields et al. 2014:Table 8-6); several of the carinated bowls have brushed vessel bodies (Figures 6-7). There are also Bailey Engraved (Figure 10), Taylor Engraved (Figure 11a), and Wilder Engraved, var. Wilder (Figure 11b) bottles and engraved bowls (Figure 12a). There is also at least one plain carinated bowl in the vessel collection (Figure 12b).

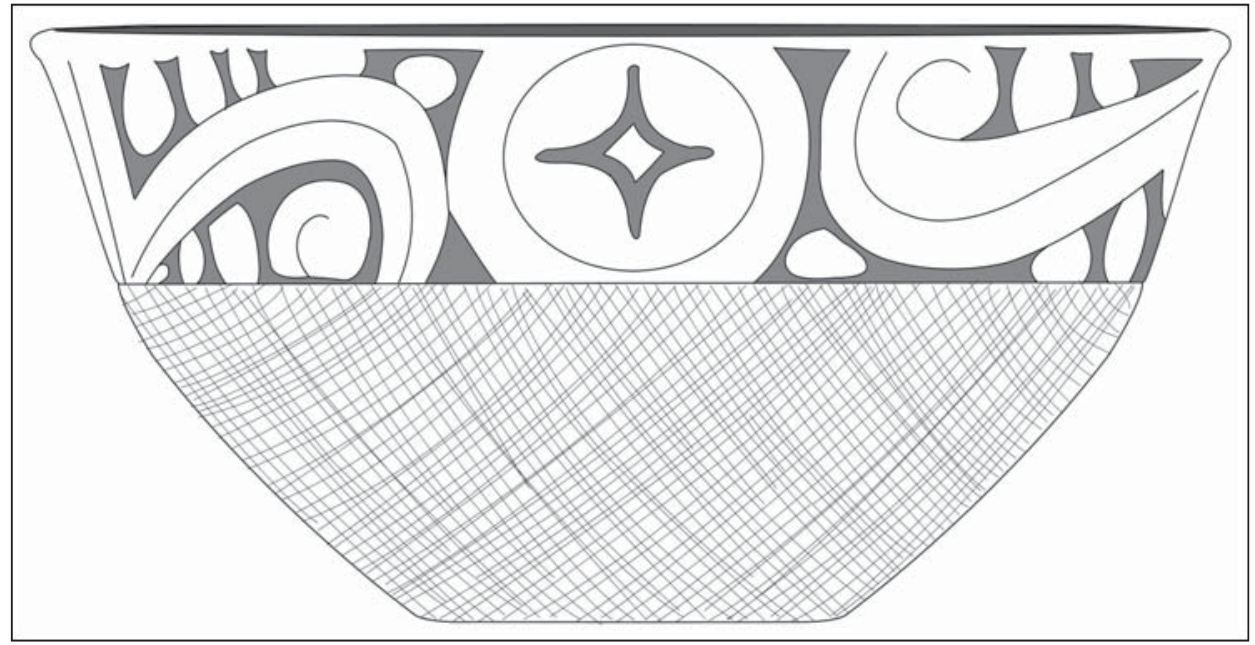

Figure 6. Ripley Engraved, var. Galt carinated bowl from one of the burial features at the Keasler site. 


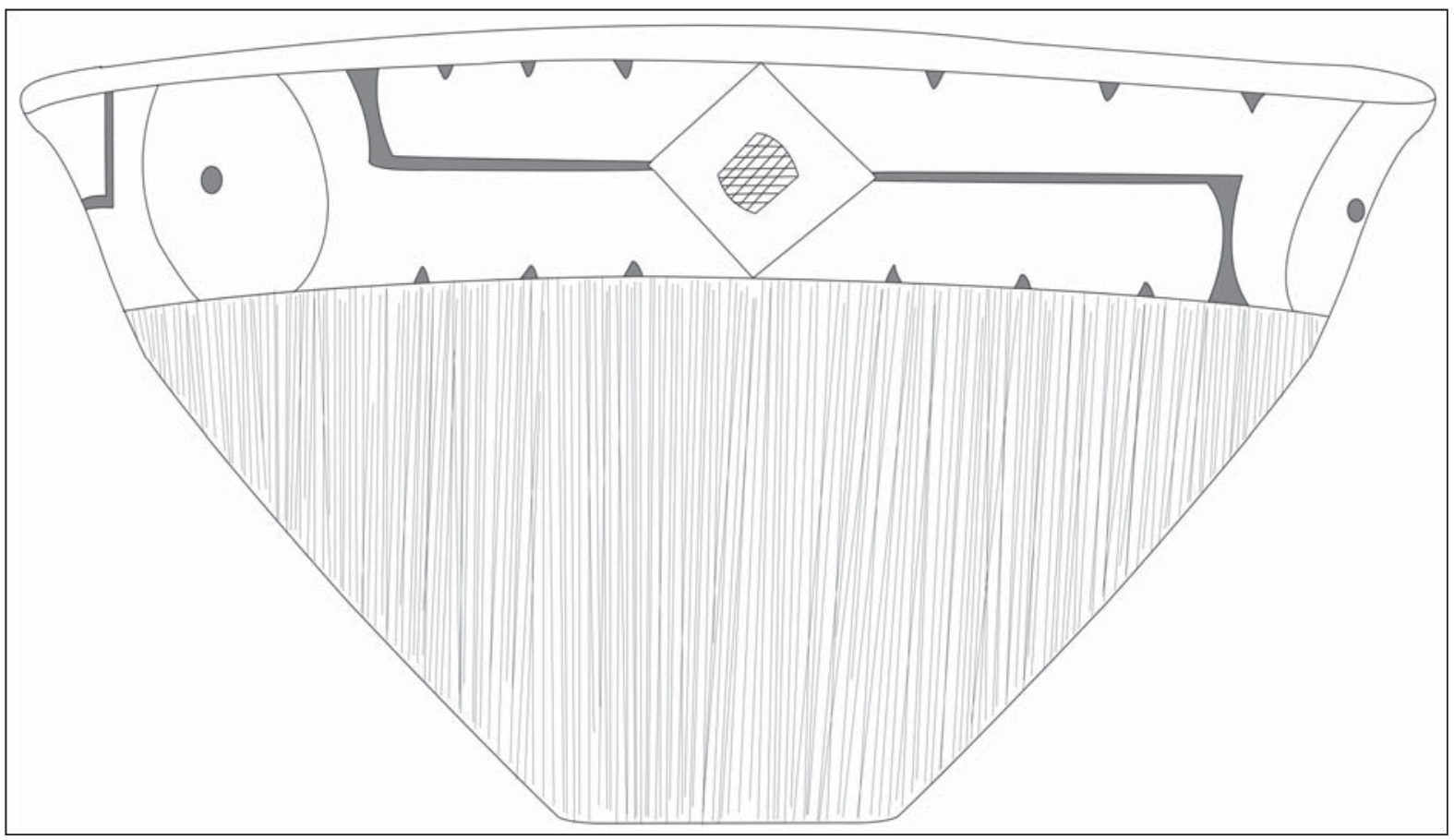

Figure 7. Ripley Engraved, var. McKinney carinated bowl from one of the burial features at the Keasler site.

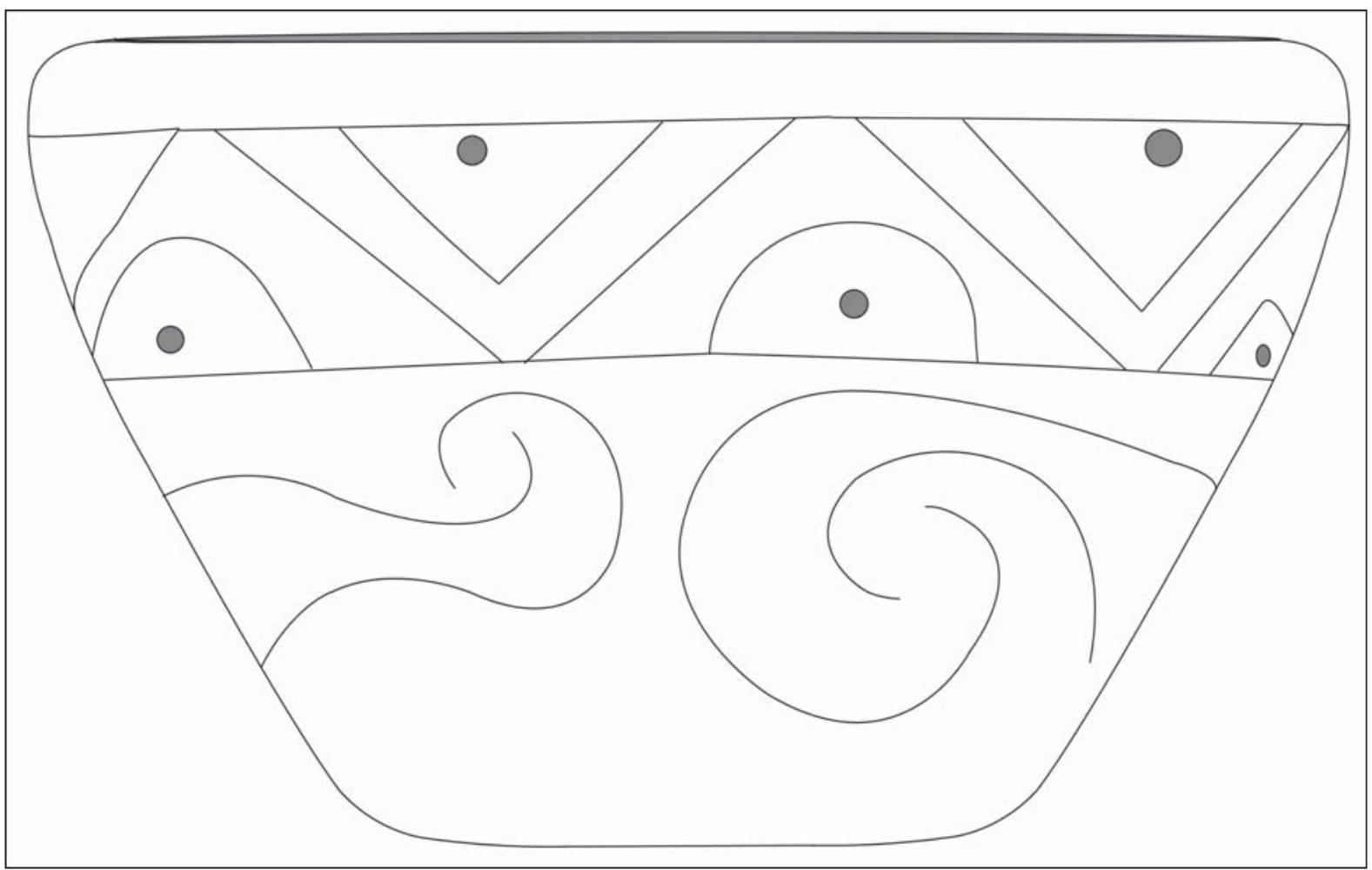

Figure 8. cf. Ripley Engraved, var. Williams carinated bowl from one of the burial features at the Keasler site. 


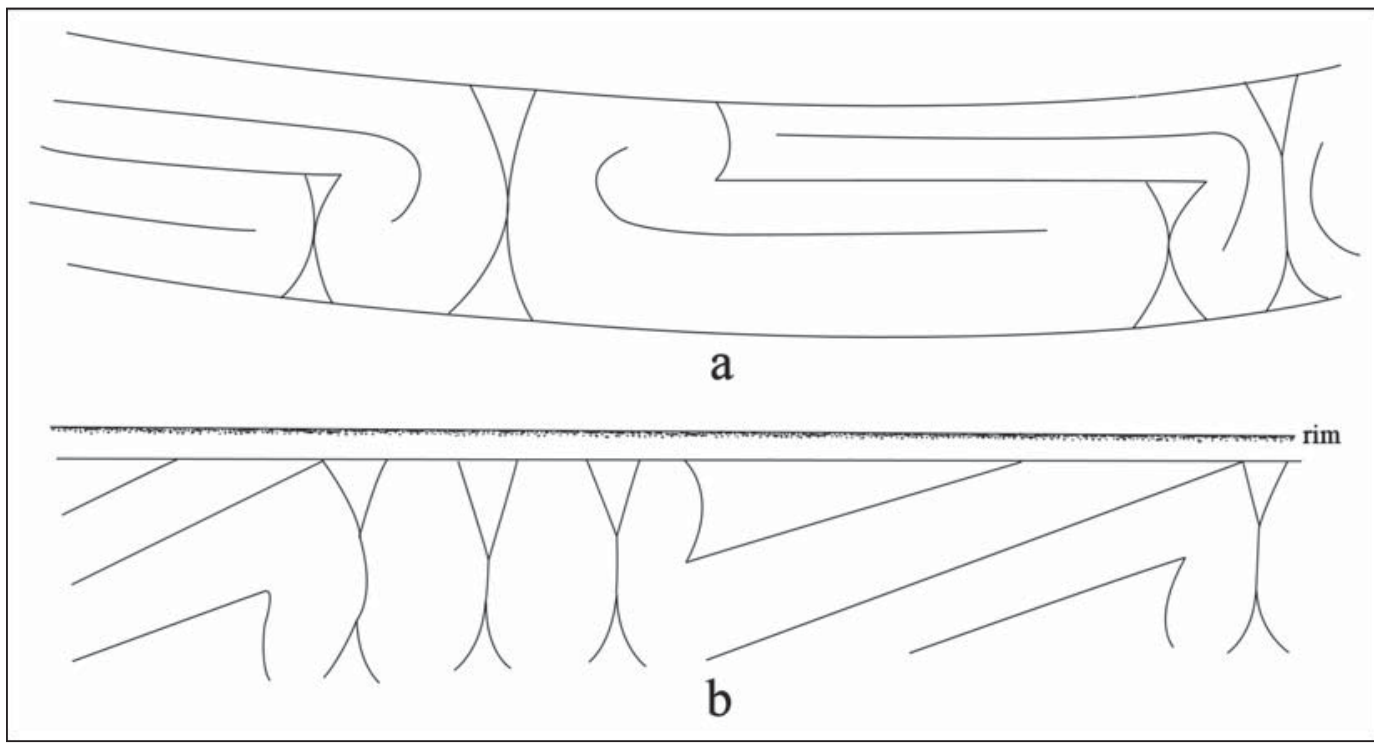

Figure 9. Decorative motifs on other Ripley Engraved vessels from burial features at the Keasler site: a, Ripley Engraved, var. Richey compound bowl; b, Ripley Engraved, var. unspecified carinated bowl.

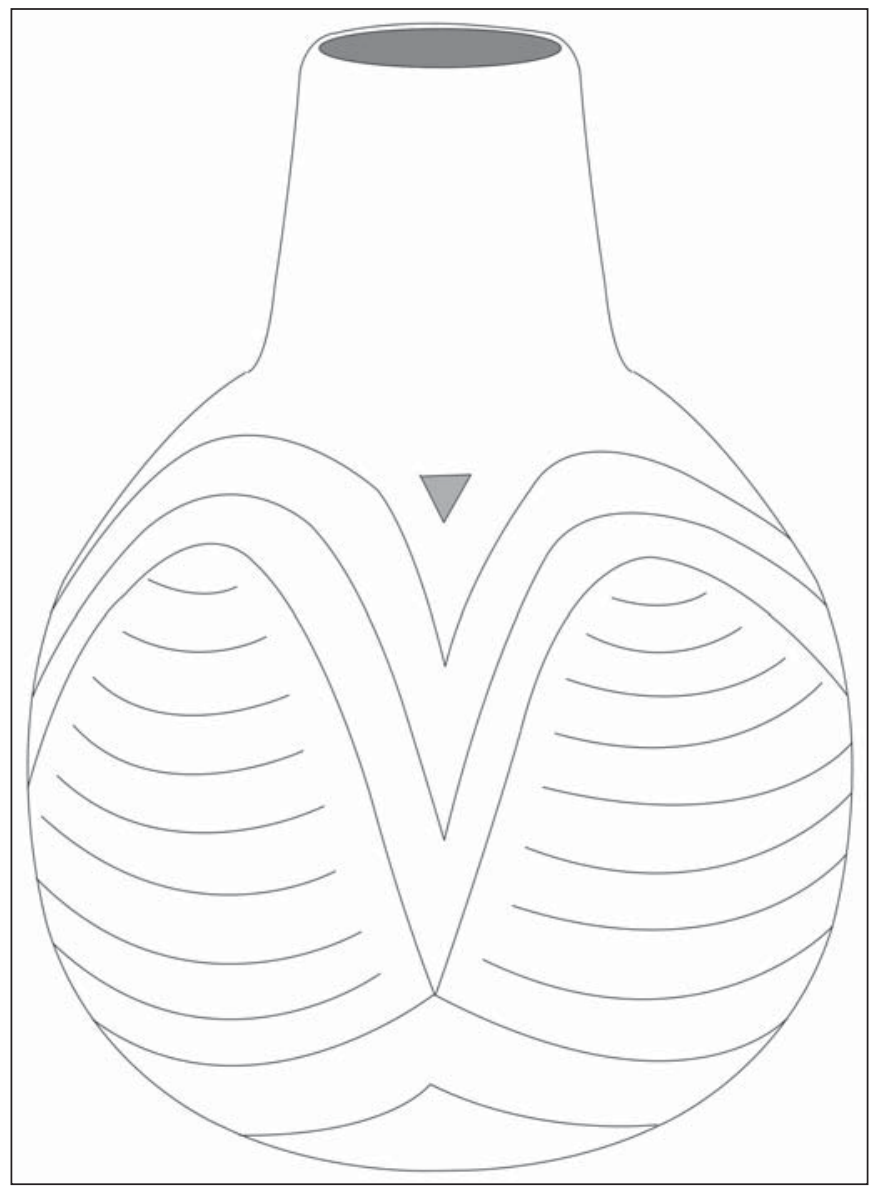

Figure 10. Bailey Engraved bottle from one of the burial features at the Keasler site. 


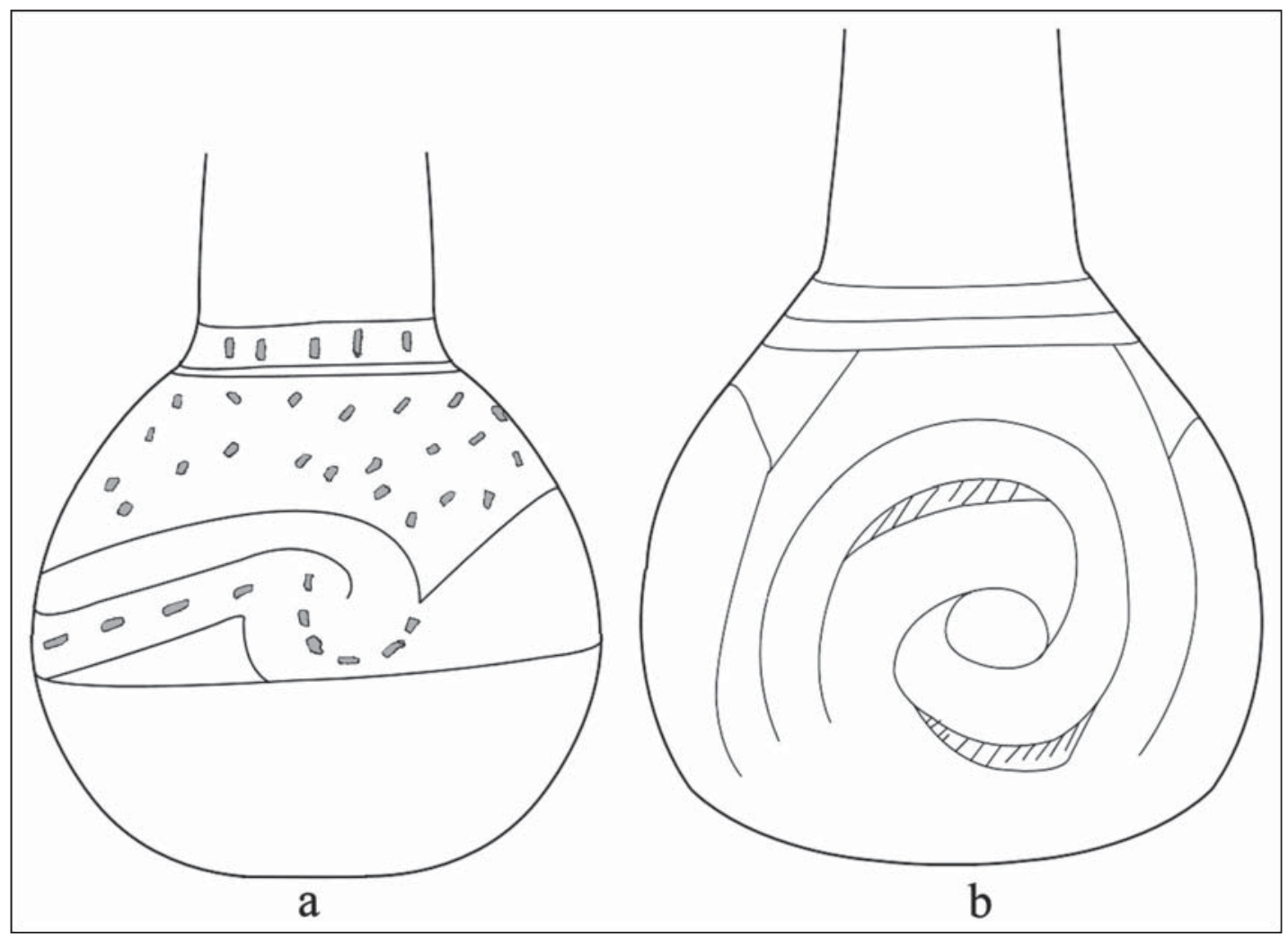

Figure 11. Engraved bottles from burial features at the Keasler site: a, Taylor Engraved; b, Wilder Engraved, var. Wilder.

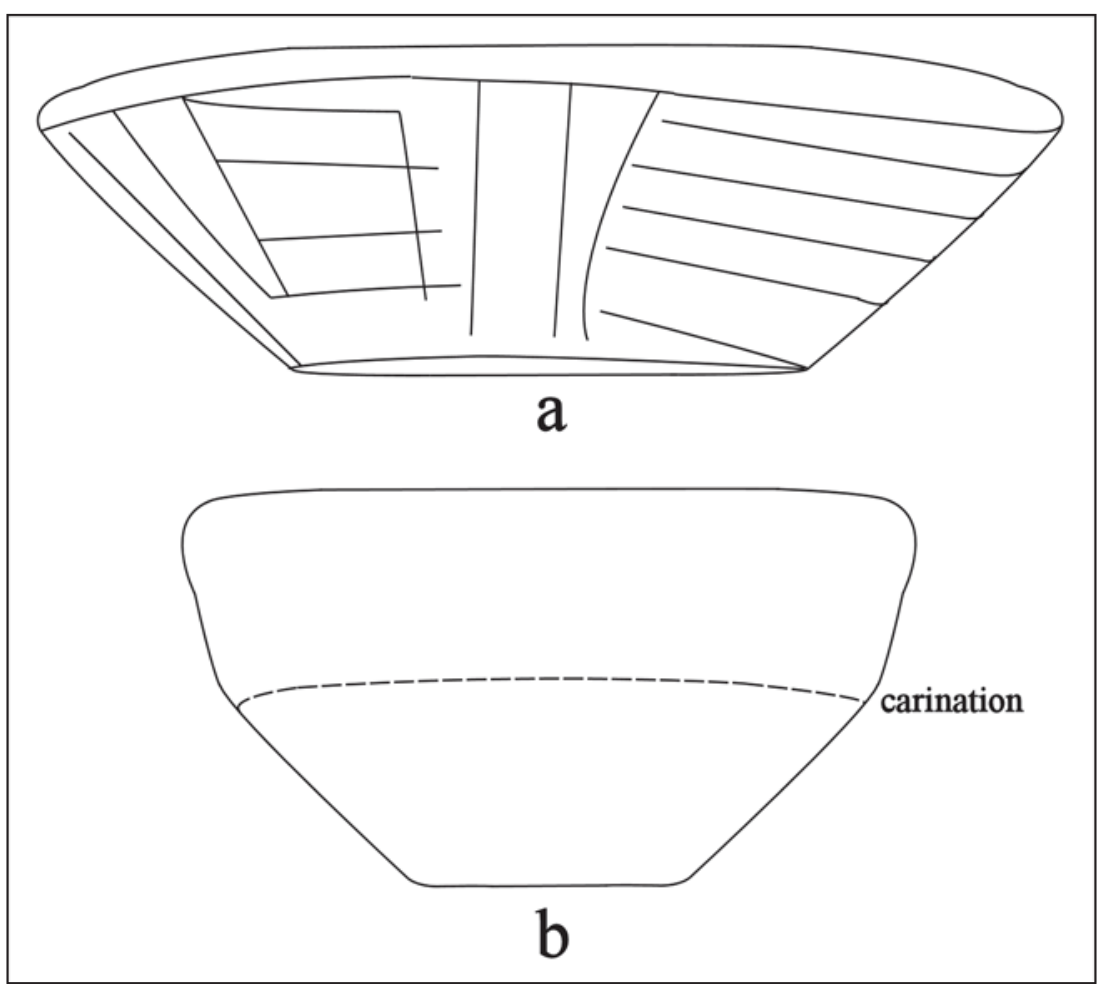

Figure 12. Other vessels from burial features at the Keasler site: a, engraved bowl; b, plain carinated bowl. 
The range of varieties of Ripley Engraved vessels among the funerary offerings suggests that this Titus phase cemetery may have been used for several generations in the $16^{\text {th }}$ and $17^{\text {th }}$ century. Ripley Engraved, var. McKinney may well be a post-A.D 1600 variety, although the chronological ordering of the many varieties of Ripley Engraved has not been fully established through either radiocarbon dating or the seriation of burial features (cf. Fields et al. 2014).

\section{SUMMARY AND CONCLUSIONS}

The Keasler site (41HS235) is a Titus phase family cemetery in the lower Little Cypress Creek basin in East Texas, a poorly known part of the Titus phase social landscape. The cemetery was excavated in the late 1970s by collectors, and there is not much detailed archaeological information available about the burial features or their funerary offerings.

The cemetery had 31 burial features, and most likely these features are the graves of adult men and women based on the size of the burial pits and the associated funerary offerings. The deceased were laid in the graves in an extended supine position, with 81 percent of the burials laid in the grave with their heads facing to the west, and the remaining burial features were buried with their heads facing to the northwest. This difference suggests that there was a diversity of beliefs about the afterlife among the ancestral Caddo peoples who used the site for the interment of the deceased.

Funerary offerings in the burials primarily include ceramic vessels - both utility and fine wares - in almost all of the burials, along with clay pipes and arrow points in only a few of the graves. The subtle differences between the two burial groups in the number and kind of funerary offerings do not provide much evidence of differential status or social rank, and the frequency of funerary offerings is at the low end of the scale in Titus phase cemeteries. The burials at the Keasler site appear to be those of common members of the Caddo community living in the lower part of the Little Cypress Creek basin. The range of decorated utility ware and fine ware vessels placed in the burial features are consistent with use of the cemetery by ancestral Caddo peoples in parts of the $16^{\text {th }}$ and $17^{\text {th }}$ centuries A.D.

\section{ACKNOWLEDGMENTS}

I would like to thank Jonathan Jarvis at the Texas Archeological Research Laboratory at The University of Texas at Austin for access to the Keasler site records. Lance Trask prepared the figures in this article.

\section{REFERENCES CITED}

Burden, D., R. C. Fields, E. F. Gadus, and V. L. Hatfield

2014 The Thomas Caldwell and A. P. Williams Cemeteries and Titus Phase Mortuary Behavior. In Testing and Data Recovery Excavations at 11 Native American Archeological Sites along the U.S. Highway 271 Mount Pleasant relief Route, Titus County, Texas, by R. C. Fields, V. L. Hatfield, D. Burden, E. F. Gadus, M. C. Wilder, and K. W. Kibler, pp. 335-433. 2 Vols. Reports of Investigations No. 168. Prewitt and Associates, Inc., Austin.

Fields, R. C., V. L. Hatfield, D. Burden, E. F. Gadus, M. C. Wilder, and K. W. Kibler

2014 Testing and Data Recovery Excavations at 11 Native American Archeological Sites along the U.S. Highway 271 Mount Pleasant relief Route, Titus County, Texas. 2 Vols. Reports of Investigations No. 168. Prewitt and Associates, Inc., Austin. 
Kelley, D. B.

2012 The Belcher Phase: Sixteenth- and Seventeenth-Century Caddo Occupation of the Red River Valley in Northwest Louisiana and Southwest Arkansas. In The Archaeology of the Caddo, edited by T. K. Perttula and C. P. Walker, pp. 411-430. University of Nebraska Press, Lincoln.

Perttula, T. K.

2012 The Character of Fifteenth- to Seventeenth-Century Caddo Communities in the Big Cypress Creek Basin of Northeast Texas. In The Archaeology of the Caddo, edited by T. K. Perttula and C. P. Walker, pp. 363-410. University of Nebraska Press, Lincoln.

Perttula, T. K., B. Nelson, and M. Walters

2012 Caddo Archaeology at the Henry Spencer Site (41UR315) in the Little Cypress Creek Basin of East Texas. Special Publication No. 20. Friends of Northeast Texas Archaeology, Pittsburg and Austin. 